\title{
INDIVIDUAL ANTIDEPRESSANT USE AND ITS ANALYSIS FOR OECD COUNTRIES ${ }^{(1)}$
}

\section{BIREYSEL ANTIDEPRESAN TÜKETIMI VE OECD ÜLKELERİNE YÖNELIK ANALIZİ}

\author{
Ayça GÜRKAN ${ }^{1}$, Ali Serdar YÜCEL $L^{2}$, Ümran SEVIL ${ }^{3}$, Mustafa TALAS ${ }^{4}$, \\ Murat KORKMAZ ${ }^{5}$, Yasemin KÜÇÜKÖZKAN ${ }^{6}$ \\ ${ }^{1-3}$ Ege University, Faculty of Nursing, İmir / Turkey \\ ${ }^{2}$ Firat University, Faculty of Sports Sciences, Elazı̆ / Turkey \\ ${ }^{4}$ Niğde Ömer Halisdemir University, Faculty of Education, Niğde / Turkey \\ ${ }^{5}$ Güven Plus Group Counselling Inc. İstanbul / Turkey \\ ${ }^{6}$ T.R. Ministry of Health, Osmaniye State Hospital, Osmaniye / Turkey
}

ORCID ID: 0000-0001-6962-3095', 0000-0003-3416-4663², 0000-0002-8973-30023, 0000-0002-0031-489X $X^{4}, 0000-0001-7925-5142^{5}, 0000-0001-7042-5432^{6}$

\section{Öz: Günümüz de bireysel ve toplumsal yaşam koşulları hızlı bir değiş̧im göstermekte ve her geçen gün yaşanan farklı olumsuzluklar ve kişisel so- runlar bireylerin psikolojik ve sosyolojik olarak sorun yaşamasına neden ol- maktadır. Bu durum bireylerin psikolojik, psikiyatrik ve sosyolojik anlamda destek almasııı bazı durumlarda ise antidepresan ilaç tüketimini artırmakta- dir. Amaç: Bu çalışma OECD ülkelerine yönelik olarak antidepresan satıs miktarı, tüketimi, kadın ve erkekler açısından sağılk algılamasına yönelik mevcut durumun belirli zaman dilimi içerisinde ortaya koyulmasını amaç- lamaktadır. Kapsam ve Yöntem: Bu bağlamda 36 OECD ülkesine ilişkin 2010 ve 2018 yillarına ait veriler derlenerek elde edilen veriler doğrultu- sunda farklı analiz yöntemleri ile karşıllaştırmalı olarak OECD ülkelerini kapsa-yan antidepresan satıs miktarı, tüketimi, kadın ve erkekler açısından sağlık algılaması incelenmiștir. Çalıșmada kullanılan veriler OECD web si- tesi üzerinden elde edilmistirir. Verilerin analizinde Eviews 8 yazılımı kulla- nılmıştır. Calısmada Birim kök analizi ve Granger Nedensellik analizinden faydalanılmıștır. Ayrıca Regresyon analizi bağımlı değişken ile bağımsız değişken arasındaki ilişkinin yönünü ve büyüklüğünün belirlenmesi için kul- lanılııs ve tüm istatisțik analizleri 0.05 anlamllılı düzeyinde test edilmiștir. Sonuç: Çalışma sonunda antidepresan satıs miktarının Kanada'da, tüketim miktarının ise İzlanda' da yüksek oranlarda olduğu tespit edilmiştir. Kadın- lara ait algılanan sağlık düzeyinin (iyi/çok iyi) Yeni Zelan-da'da, erkeklerde ise Kanada' da daha olumlu olduğu ayrica antidepresan satış miktarnndaki bir birimlik artışın, kadılnarın iyi/çok iyi olarak algilanan sağlık düzeylerinde 4.56 birim artış, erkeklerin iyi/cok iyi olarak algilanan sağlk düzeylerinde ise 4.87 birim artış, tüketim miktarındaki bir birimlik artısıın ise, kadin-ları
iyi/çok iyi olarak algııanan sağlık düzeylerinde 0.99 birim artış sağladığı sonucuna ulaşılmıştır. \\ Anahtar Kelimeler: Antidepresan, OECD, Erkek, Kadın, Sağılk Algısı, Ilaç}

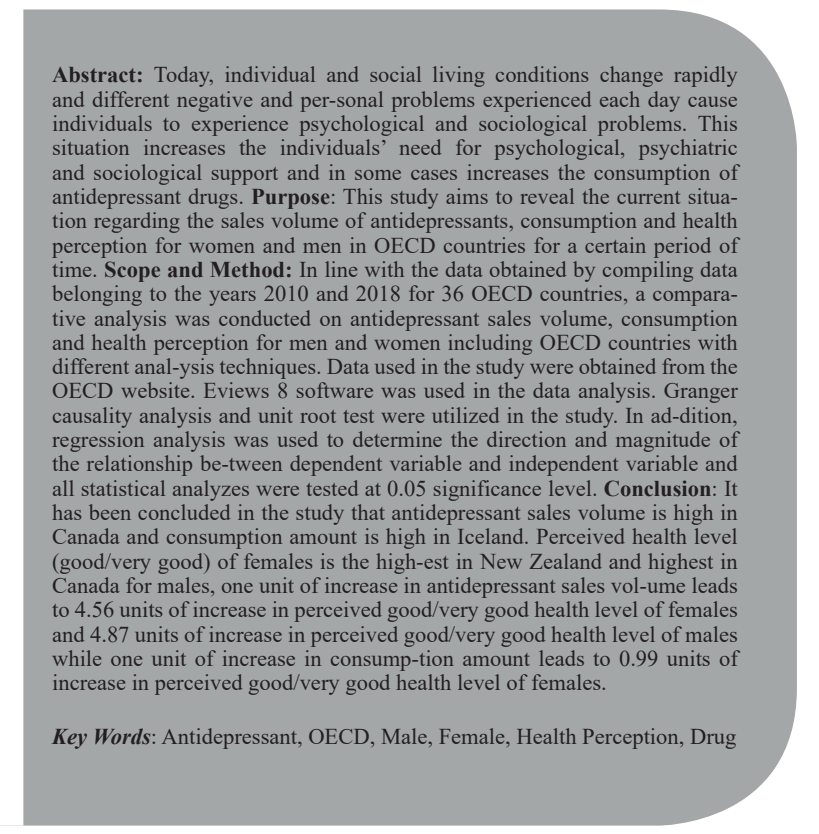

Doi: $10.17363 /$ SSTB.2019.32.5

(1) Sorumlu Yazar, Corresponding Author: Ayça GÜRKAN “Dr. Öğr. Üyesi - MD”, Ege University, Ege University, Faculty of Nursing, İzmir / Turkey, ayca.gurkan@gmail.com, Geliş Tarihi / Date of Arrival: 14.12.2018, Kabul Tarihi / Date of Acceptance: 24.04.2019, Makalenin Türü: Type of Article: (Araştırma-Uygulama; ResearchApplication) Çıkar Çatışması, Yok - Conflict of Interest, No, Etik Kurul Raporu veya Kurum İzin Bilgisi-Ethical Board Report or Institutiunal Approval, Yok/No 
International Refereed Academic Journal of Sports, Health and Medical Sciences July - August - September Issue: 32 Summer Term Year: 2019

Uluslararası Hakemli Akademik Spor Sağlık ve Tıp Bilimleri Dergisi

Temmuz - Ağustos - Eylül Sayı: 32 Yaz Dönemi Yıl: 2019

ID:461 K:129

ISSN Print: 2146-8508 Online 2147-1711

(ISO 18001-OH-0090-13001706 / ISO 14001-EM-0090-13001706 / ISO 9001-QM-0090-13001706 / ISO 10002-CM-0090-13001706)

(TRADEMARK)

(2015/04315- 2015-GE-18972)

\section{INTRODUCTION}

Personal lifestyle varies among persons, cultures, believes, communities and regions. Psychological structure also changes in many ways and causes instant changes. This situation has significant effects on individuals and societies.

Our lifestyle and belief concepts are changing with each passing day. We can collect and diversify the reasons of these changes under many factors. But it would be accurate to say that the most important reasons are living standards and the sociological structure we are in.

Individuals and societies are adopting new life styles or trying to keep up with these life styles day by day by their living standards.

As an important dimension, daily events related to the necessities of living that individuals and societies are obliged to do cause them to lead a psychologically monotonous life, which reveals the fact that it causes psychologically negative conditions for individuals and societies.

Especially the habit of eating and drinking, a monotonous and sedentary life, irregular sleep, unqualified and various personal relationships, social events, political reasons, sociological and political effects, economic factors and many other reasons cause the individual to have psychological problems.

In line with the above-mentioned reasons, psychological change goes beyond the will and power of the individual in some cases and necessitates external support.

The aim of this application study performed related to OECD countries is to analyze the dimension of antidepressant purchased and consumed within the scope of the individual dimension with different techniques and to give the results of the findings obtained.

\section{THEORETICAL FRAMEWORK and LI- TERATURE REVIEW}

Human is a being that is obliged to work. The people who have to work to maintain their life, to meet the standards of living and to meet their needs come across different problems in their working life every day (Berger, 1961: 213).

Economic power and the wage earnt are an important factor in shaping individual's living standards, especially the social status (Tinar, 1996: 3).

Social relations and living standards are the most important factors in shaping the individual's psychological and health status. Temporal structure, bilateral relations, physical dimension, intellectual structure, economic power, social status and social de- 
International Refereed Academic Journal of Sports, Health and Medical Sciences

July - August - September Issue: 32 Summer Term Year: 2019

Uluslararası Hakemli Akademik Spor Sağlık ve Tıp Bilimleri Dergisi

Temmuz - Ağustos - Eylül Sayı: 32 Yaz Dönemi Yıl: 2019

ID:461 K:129

ISSN Print: 2146-8508 Online 2147-1711

(ISO 18001-OH-0090-13001706 / ISO 14001-EM-0090-13001706 / ISO 9001-QM-0090-13001706 / ISO 10002-CM-0090-13001706)

(TRADEMARK)

(2015/04315- 2015-GE-18972)

velopments result in significant impacts on individual's daily life (Giddens, 2000: 237326).

Inactivity and physical monotony are the most important problems of today's people. Sports and physical activity significantly affect the physical and psychological health factors of the individual. This situation is not only an obstacle for an individual to lead a healthier life, but also affects a healthier life. Sedentary life causes an increased risk for cancer for the individual. ${ }^{1}$

When many literature and application studies are examined, sedentary life and monotonous life, which are shown to have an effect on the majority of psychological problems, significantly decrease the individual's quality of life. $^{2}$

A newspaper report emphasizes that the consumption of antidepressant drugs has increased by $27 \%$ in the last 5 years. In the same report, it has been pointed out that 9 million individuals have provided support by seeing mental and neurological specialists / doctors in recent years. ${ }^{3}$

1 https://www.mcdonalds.com.tr/kampanyalar/ kulahima-anlat\#utm_source=programmatic\&utm medium $=$ cpc\&utm_campaign $=$ banner

2 http://www.turkishtimedergi.com/genel/ise-girismulakatinda-basarili-olmak/

3 https://onedio.com/haber/turkiye-de-antidepresankullanimi-son-5-yilda-yuzde-27-artti-pekineden- 851773
When we look at the developed world countries, we can say that the use of antidepressant drugs has increased rapidly in many developed world countries.

This situation shows that the individual and social structure is deteriorated, living standards and ways have changed, individual expectations and demands are changing day by day and the rate of unhappiness also increases.

In a study conducted by the World Health Organization WHO (2002), it was emphasized that expansion of rational drug consumption and use is an obligation. In the study which indicates the fact that unconscious drug consumption has become an individual problem even in the slightest health problems, it is stated that individual drug consumption and support increases with each passing day (WHO, 2002).

Individual and social structure changes cause many psychological problems, which increases the consumption of psychological and antidepressant drugs and raises the rate of use (Laing, 1990: 101).

Unconscious drug consumption has become an economic problem for countries. Increasing drug consumption and use is an important risk for the country's economy, and it also causes different problems to arise (Aydin, 2012: 57). 
International Refereed Academic Journal of Sports, Health and Medical Sciences July - August - September Issue: 32 Summer Term Year: 2019

Uluslararası Hakemli Akademik Spor Sağlık ve Tıp Bilimleri Dergisi Temmuz - Ağustos - Eylül Sayı: 32 Yaz Dönemi Yıl: 2019 ID:461 K:129

ISSN Print: 2146-8508 Online 2147-1711

(ISO 18001-OH-0090-13001706 / ISO 14001-EM-0090-13001706 / ISO 9001-QM-0090-13001706 / ISO 10002-CM-0090-13001706) (TRADEMARK)

Increasing individual drug consumption and individual expenditure on different drug types in recent years points to an approaching significant problem in terms of public measures. Ignoring the necessity of an emergency response to this situation creates a different ground for different problems to occur (Ulusoy and Sunmak, 2011: 310).

Along with the change in some personal problems, changes in living standards generate a significant impact on the psychology of the individual. This situation requires the individual to be inadequate and to receive external support. Antidepressant medication is the first thing suggested by the specialist / physician as a remedy for the problems an individual has experienced when $\mathrm{s} / \mathrm{he}$ feels inadequate or needs external support. This situation increases the consumption of antidepressant drugs and causes individuals to become dependent (Yapıc1 et al., 2001: 459).

When we look at developed world countries in the last 10 years, we can say that drug expenditure and its significant impact on the economy have an important dimension. "It is $7.2 \%$ in Italy, $9.5 \%$ in the Netherlands, $12.9 \%$ in the USA, $16.0 \%$ in France, $7.4 \%$ in Denmark, $33.6 \%$ in Hungary, $7.3 \%$ in Norway, $24.8 \%$ in Greece, $14.8 \%$ in Germany, and $27.1 \%$ in Mexico and the OECD average is $16.3 \% "(\mathrm{OECD}, 2012)$.
There is also a significant difference in the relationship between the purchased and consumed drug. Although the high proportion of prescribed drugs is remarkable within the relationship between the applicant and the referenced, the imbalance in the consumption of prescribed drugs also poses a separate problem.

For instance, although many medicines prescribed by the physician are taken from the pharmacy, the use is unfortunately not realized and discarded.

In a research conducted by Ankara Chamber of Commerce in 2006, the fact that the rate of prescribed but trashed drugs in Turkey is $7 \%$ constitute the picture of what a great economic loss is experienced. In addition, it is a significant problem that the cost of unused medicines which are taken from the pharmacy and exceeding the expiration date at home or not used at all constitutes a burden of 500 million dollars on the country's economy (Şenol, 2010: 145).

The same problem applies to developed world countries. Emphasis is laid on the importance of rational drug consumption in many world and developed world countries. Although the importance of individual awareness is brought to the forefront, public service aids are created to raise awareness that it is not right 


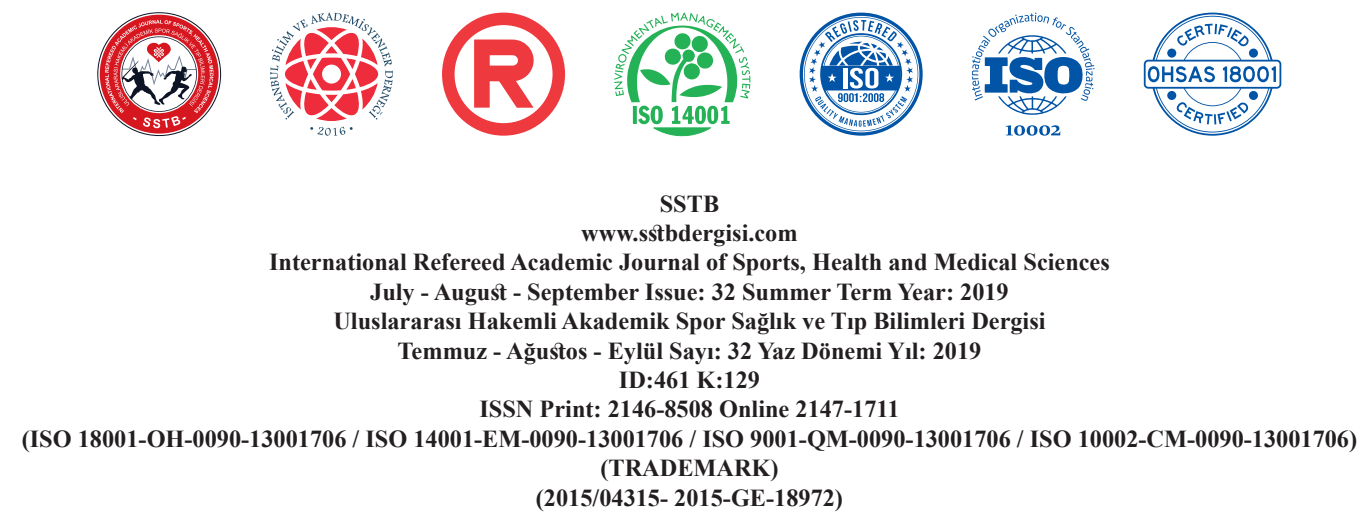

to resort to drug consumption in every negative situation.

Considering the psychological problems, there is also a lot of scientific research on the fact that many antidepressant drugs used are actually unnecessary, or their use is not right at that moment. These studies indicate that individuals should seek answers to their problems with different social activities or psychological therapies before drug consumption.

It is emphasized that it is not right to use "antidepressant" in every problem. Increasing diversity of the problems experienced in today's conditions and changing or difficult living standards make the psychological struggle of individuals impossible. This reality is coming to light every day. This situation increases the consumption of individual drug "antidepressants". However, it is necessary to know the fact that it is not the right choice to use antidepressant drugs after each psychological problem.

Although such methods as antidepressant drug use (Berman et al., 2000), psychotherapy, electroconvulsive therapy (Schloesser et al., 2015) and phototherapy (Golden et al., 2005) are used effectively in the treatment of depression, which is among the most important diseases of our age, it has been stated that sports / exercise is used as an alternative treatment method for these diseases (Mead et al., 2008; Ströhle, 2009; Fariz, 2015; Jeong et al., 2016).

It has been revealed in the researches that doing sports/exercise regularly reduce the depression level (Perraton et al., 2010; Aylaz et al., 2011; Stanton and Reaburn, 2014; Dik et al., 2016) and it is one of the mostly used treatment methods to cure depressed patients recently (Conn, 2010; Carek et al., 2011; Krogh et al., 2011).

Sports activities, music, sightseeing, cultural tours, reading books, different fine arts or social activities that support personal development will improve our healing from the psychological problems we have experienced and reduce the consumption of antidepressant drugs we have to use.

\section{PURPOSE}

Variation and change of today's individual lifestyle from the past which includes differences from person to person shapes the way of life of individuals. The different negative and personal problems experienced each day reveal the psychological and sociological problems and internal struggle of individuals. This situation increases individuals' need for psychological, psychiatric and sociological support and in some cases increases their antidepressant drug consumption. In this study, a research and application has been carried out for OECD countries and data belonging 
International Refereed Academic Journal of Sports, Health and Medical Sciences July - August - September Issue: 32 Summer Term Year: 2019

Uluslararası Hakemli Akademik Spor Sağlık ve Tıp Bilimleri Dergisi

Temmuz - Ağustos - Eylül Sayı: 32 Yaz Dönemi Yıl: 2019 ID:461 K:129

ISSN Print: 2146-8508 Online 2147-1711

(ISO 18001-OH-0090-13001706 / ISO 14001-EM-0090-13001706 / ISO 9001-QM-0090-13001706 / ISO 10002-CM-0090-13001706) (TRADEMARK)

(2015/04315- 2015-GE-18972)

to the years 2010 and 2018 have been compiled and analyzed with different analysis methods in line with the obtained data. The aim of the study was to analyze antidepressant sales volume and consumption and to compare consumption between men and women.

\section{LIMITATIONS of RESEARCH}

Data belonging to the data of OECD countries were used in the study. These data only belong to the years 2010 and 2018. The limitations of the research include men and women, consumption and sales volume.

\section{CONTRIBUTION to LITERATURE}

In the new studies to be conducted in the field, the causalities of the relationship between sales and consumption amount and the perceived effect of health perception level on women and men were examined with different analysis techniques. The findings obtained indicate that which fields and reasons are concentrated in future researches. This situation has a significant impact on the researchers' perspective on the field and causality and provides guidance. This study provides a new contribution to the literature on statistics and causality analyzes and it also suggests that different methods can be used for field researchers.

\section{METHOD}

In this study, the relationship between the health variables was determined in four ca- tegories belonging to the OECD countries as obtained from the website of OECD. These variables are as follows;

- Sales volume of antidepressants

- Consumption amount of antidepressants

- Perceived health level (good/very good) - Female

- Perceived health level (good/very good) - Male

\section{SCOPE}

Annual data between 2010 and 2018 were analyzed in this study. Data were compiled for 36 OECD countries.

\section{FINDINGS and ANALYSIS}

Eviews 8 software was used in this analysis. Basic statistics were used to obtain summary information about variables. Unit root analysis was used to test whether variables have unit roots and therefore can be used in longterm analysis. Granger Causality analysis was used to determine the direction of the relationship between the variables. Regression analysis was used to determine the direction and magnitude of the relationship between the dependent variable and the independent variable. All statistical analyzes were tested at 0.05 significance level. 
SSTB

www.sstbdergisi.com

International Refereed Academic Journal of Sports, Health and Medical Sciences

July - August - September Issue: 32 Summer Term Year: 2019

Uluslararası Hakemli Akademik Spor Sağlık ve Tıp Bilimleri Dergisi

Temmuz - Ağustos - Eylül Sayı: 32 Yaz Dönemi Yıl: 2019 ID:461 K:129

ISSN Print: 2146-8508 Online 2147-1711

(ISO 18001-OH-0090-13001706 / ISO 14001-EM-0090-13001706 / ISO 9001-QM-0090-13001706 / ISO 10002-CM-0090-13001706) (TRADEMARK)

(2015/04315- 2015-GE-18972)

\section{BASIC INFORMATION RELATED to OECD HEALTH STATISTICS}

Antidepressant sales are highest in Canada among OECD countries. The first three co- untries are Canada, Iceland and Spain while the last three are Latvia, New Zealand and Mexico respectively.

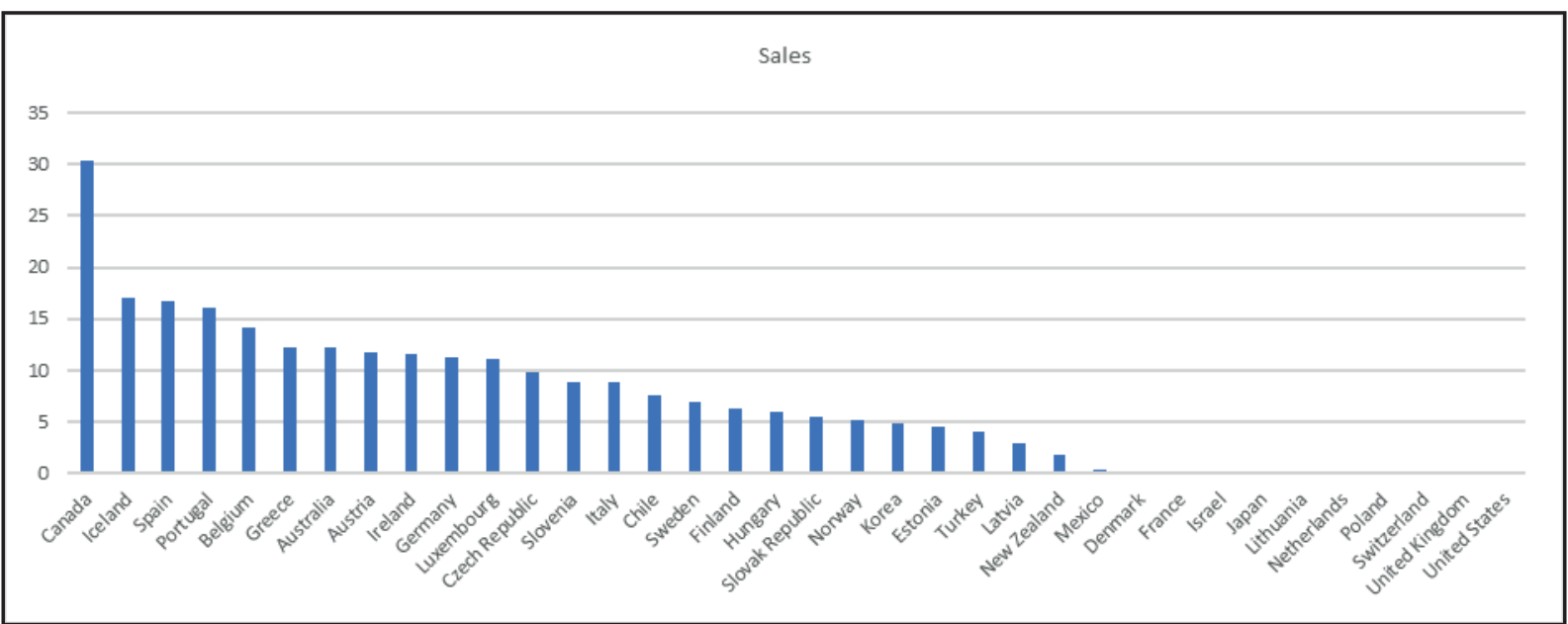

Antidepressant consumption amount is highest in Iceland among OECD countries. The first three countries are Iceland, Canada and
Australia respectively while the last three countries are Hungary, Korea and Latvia. 

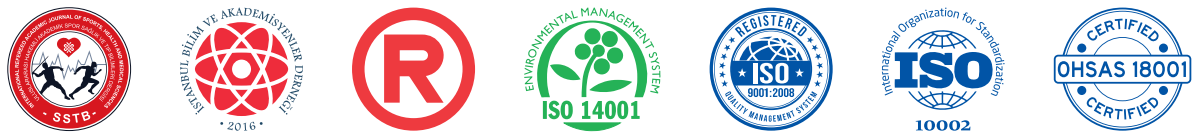

SSTB

www.sstbdergisi.com

International Refereed Academic Journal of Sports, Health and Medical Sciences

July - August - September Issue: 32 Summer Term Year: 2019

Uluslararası Hakemli Akademik Spor Sağlık ve Tıp Bilimleri Dergisi

Temmuz - Ağustos - Eylül Sayı: 32 Yaz Dönemi Yıl: 2019

ID:461 K:129

ISSN Print: 2146-8508 Online 2147-1711

(ISO 18001-OH-0090-13001706 / ISO 14001-EM-0090-13001706 / ISO 9001-QM-0090-13001706 / ISO 10002-CM-0090-13001706) (TRADEMARK)

(2015/04315- 2015-GE-18972)

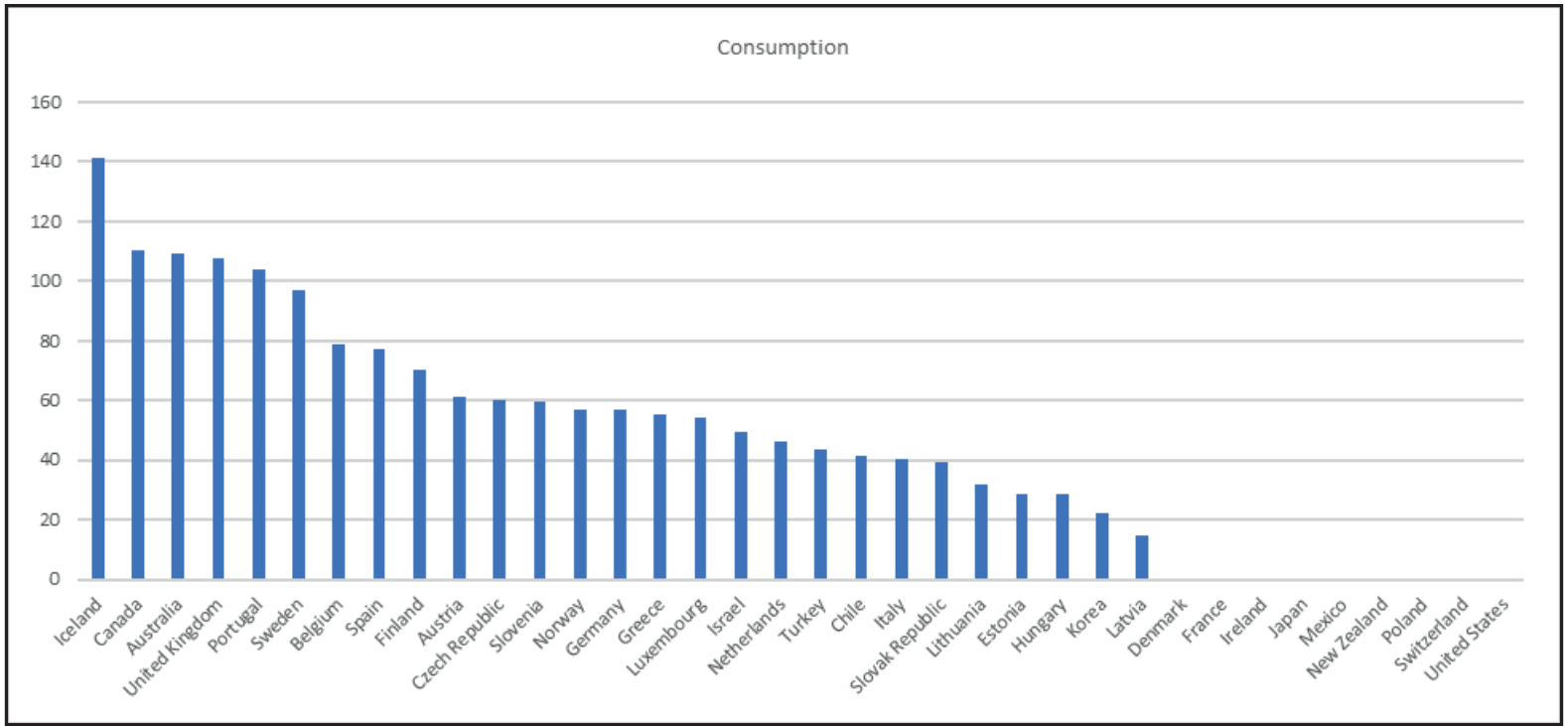

Perceived health level (good / very good) of New Zealand, Canada and the United States females is highest in New Zealand among respectively while the last three countries are OECD countries. The first three countries are Lithuania, Latvia and Korea respectively.

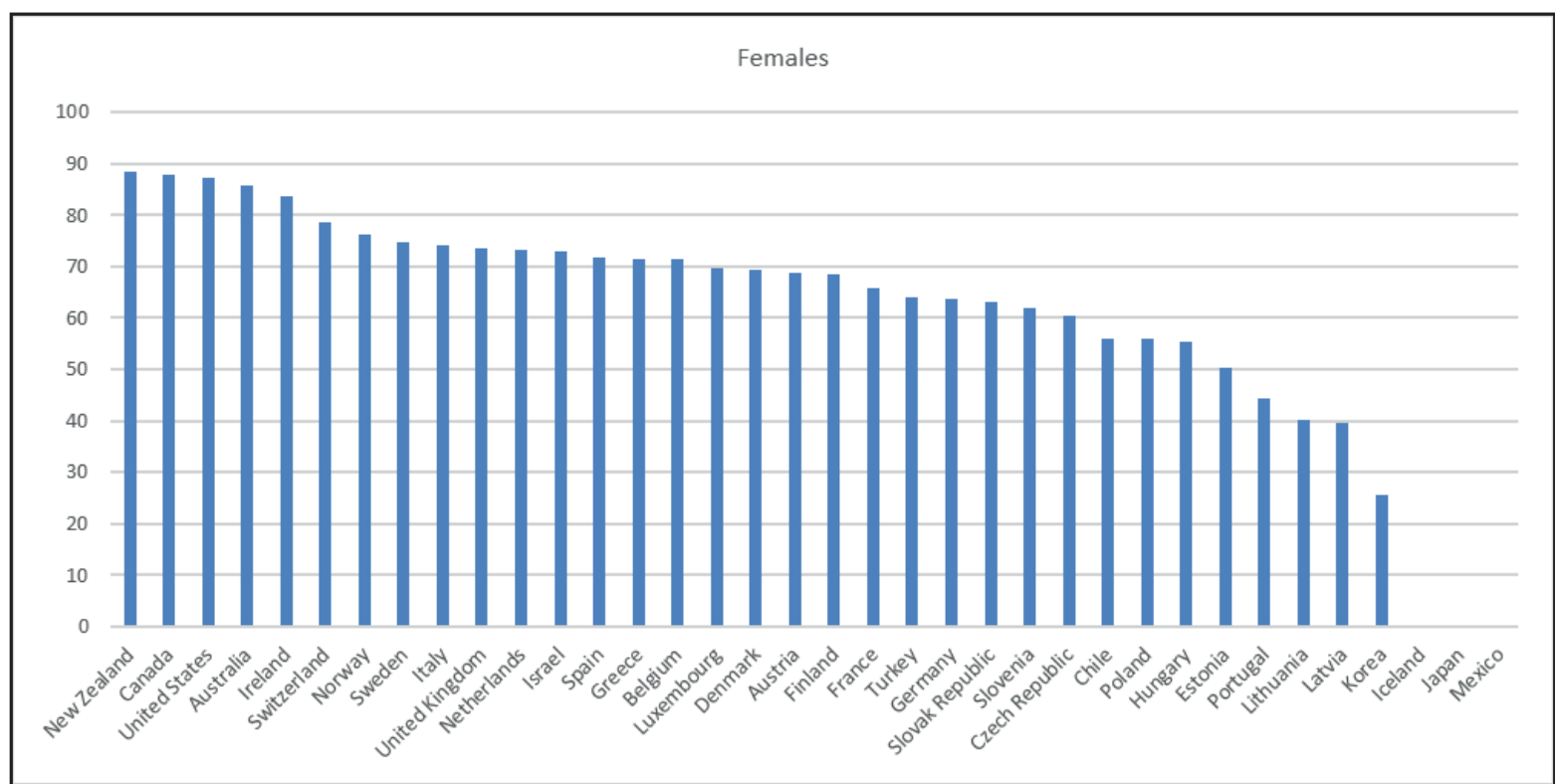



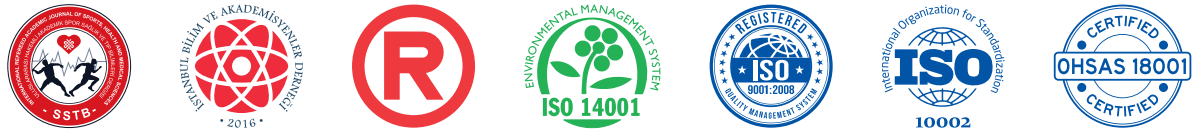

SSTB

www.sstbdergisi.com

International Refereed Academic Journal of Sports, Health and Medical Sciences

July - August - September Issue: 32 Summer Term Year: 2019

Uluslararası Hakemli Akademik Spor Sağlık ve Tıp Bilimleri Dergis

Temmuz - Ăgustos - Eylül Sayı: 32 Yaz Dönemi Yıl: 2019 ID:461 K:129

ISSN Print: 2146-8508 Online 2147-1711

(ISO 18001-OH-0090-13001706 / ISO 14001-EM-0090-13001706 / ISO 9001-QM-0090-13001706 / ISO 10002-CM-0090-13001706) (TRADEMARK)

(2015/04315- 2015-GE-18972)

Perceived health level (good / very good) of the United States and New Zealand respectimales is highest in Canada among OECD covely while the last three countries are Latvia, untries. The first three countries are Canada, Lithuania and Korea respectively.

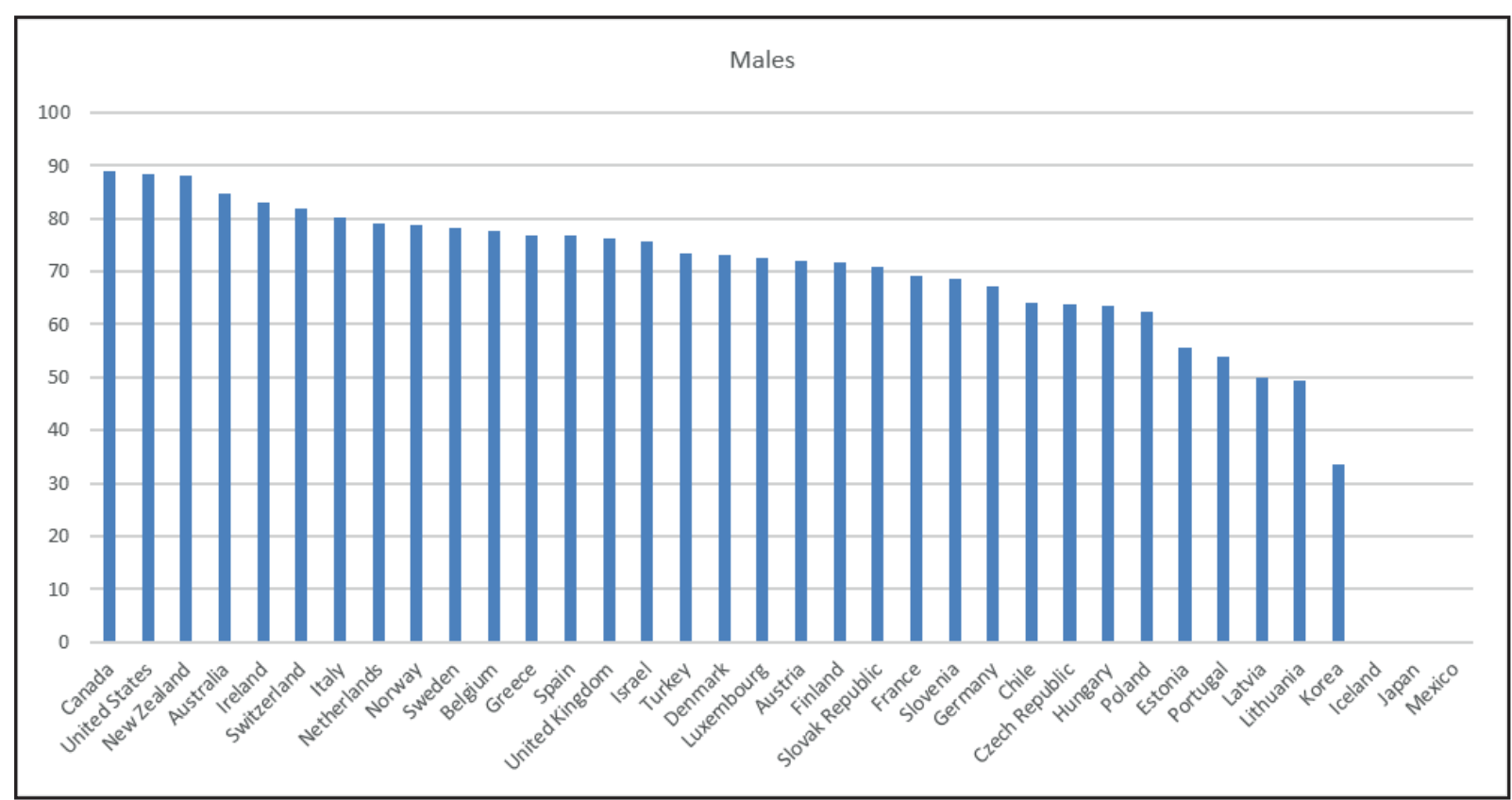

UNIT ROOT ANALYSIS

\section{ANTIDEPRESSANT SALES VOLUME UNIT ROOT ANALYSIS RESULTS}

According to the unit root analysis, $\mathrm{H} 0$ hypothesis is rejected due to the fact that probabi- lity values are bigger than confidence level of 0.05 . Thus, it has been determined that antidepressant sales volume does not contain unit root; therefore, it can be used in future analyses. 


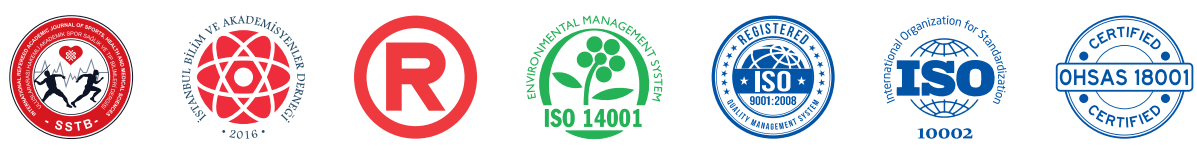

SSTB

www.sstbdergisi.com

International Refereed Academic Journal of Sports, Health and Medical Sciences

July - August - September Issue: 32 Summer Term Year: 2019

Uluslararası Hakemli Akademik Spor Sağlık ve Tıp Bilimleri Dergisi

Temmuz - Ağustos - Eylül Sayı: 32 Yaz Dönemi Yıl: 2019

ID:461 K:129

ISSN Print: 2146-8508 Online 2147-1711

(ISO 18001-OH-0090-13001706 / ISO 14001-EM-0090-13001706 / ISO 9001-QM-0090-13001706 / ISO 10002-CM-0090-13001706)

(TRADEMARK)

(2015/04315- 2015-GE-18972)

\begin{tabular}{|c|c|c|c|c|}
\hline \multicolumn{5}{|c|}{ Panel unit root test: Summary } \\
\hline \multicolumn{5}{|l|}{ Series: SALES } \\
\hline \multicolumn{5}{|l|}{ Sample: 20102018} \\
\hline \multicolumn{5}{|c|}{ Exogenous variables: Individual effects } \\
\hline \multicolumn{5}{|c|}{ Newey-West automatic bandwidth selection and Bartlett kernel } \\
\hline & & \multicolumn{3}{|c|}{ Cross- } \\
\hline Method & Statistic & Prob.** & $\begin{array}{l}\text { secti- } \\
\text { ons }\end{array}$ & Obs \\
\hline \multicolumn{5}{|c|}{ Null: Unit root (assumes common unit root process) } \\
\hline Levin, Lin \& Chu $t^{*}$ & -5.51005 & 0.0000 & 28 & 198 \\
\hline
\end{tabular}

Null: Unit root (assumes individual unit root process)

ANTIDEPRESSANT CONSUMPTION AMOUNT UNIT ROOT ANALYSIS RESULTS

According to the unit root analysis, $\mathrm{H} 0$ hypothesis is rejected due to the fact that probabi- lity values are bigger than confidence level of 0.05 . Thus, it has been determined that antidepressant consumption amount does not contain unit root; therefore, it can be used in future analyses.

\begin{tabular}{|c|c|c|c|c|}
\hline \multicolumn{5}{|c|}{ Panel unit root test: Summary } \\
\hline \multicolumn{5}{|c|}{ Series: CONSUMPTION } \\
\hline \multicolumn{5}{|l|}{ Sample: 20102018} \\
\hline \multicolumn{5}{|c|}{ Exogenous variables: Individual effects } \\
\hline \multicolumn{5}{|c|}{ Newey-West automatic bandwidth selection and Bartlett kernel } \\
\hline & & \multicolumn{3}{|c|}{ Cross- } \\
\hline Method & Statistic & Prob.** & $\begin{array}{l}\text { secti- } \\
\text { ons }\end{array}$ & Obs \\
\hline \multicolumn{5}{|c|}{ Null: Unit root (assumes common unit root process) } \\
\hline Levin, Lin \& Chu t* & -2.12469 & 0.0168 & 28 & 191 \\
\hline
\end{tabular}

Null: Unit root (assumes individual unit root process) 
SSTB

www.sstbdergisi.com

International Refereed Academic Journal of Sports, Health and Medical Sciences

July - August - September Issue: 32 Summer Term Year: 2019

Uluslararası Hakemli Akademik Spor Sağlık ve Tıp Bilimleri Dergis

Temmuz - Ağustos - Eylül Sayı: 32 Yaz Dönemi Yıl: 2019

ID:461 K:129

ISSN Print: 2146-8508 Online 2147-1711

(ISO 18001-OH-0090-13001706 / ISO 14001-EM-0090-13001706 / ISO 9001-QM-0090-13001706 / ISO 10002-CM-0090-13001706) (TRADEMARK)

(2015/04315- 2015-GE-18972)

PERCEIVED HEALTH LEVEL UNIT ROOT ANALYSIS RESULTS

According to the unit root analysis, H0 hypothesis is rejected due to the fact that probabi- lity values are bigger than confidence level of 0.05 . Thus, it has been determined that perceived happiness level for both genders does not contain unit root and so, it can be used in future analyses.

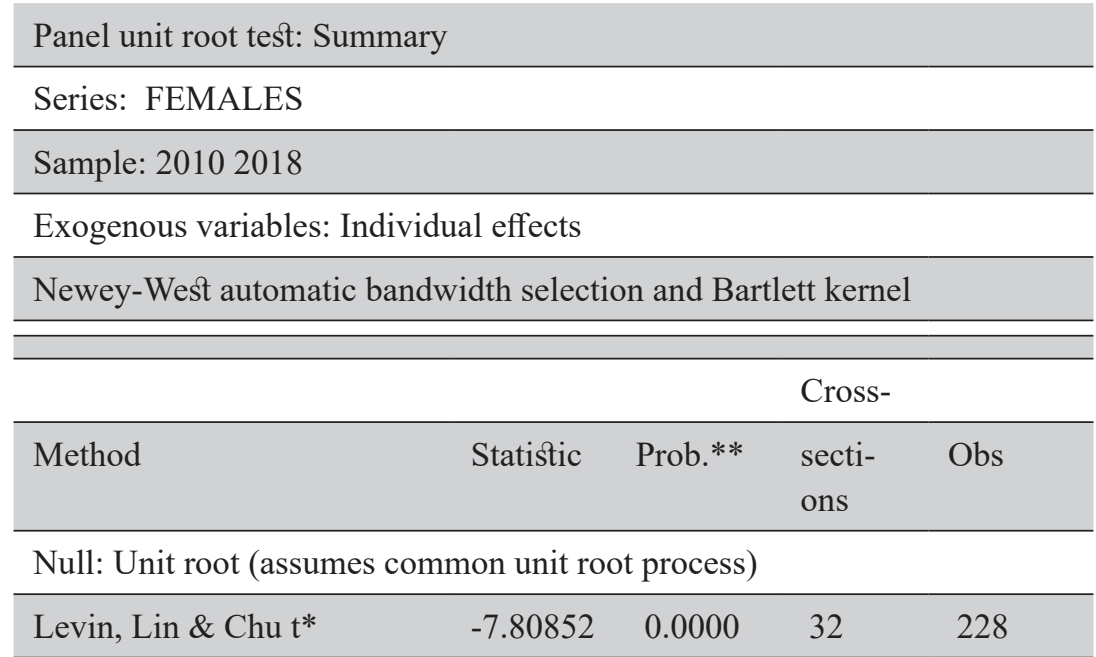

\begin{tabular}{|c|c|c|c|c|}
\hline \multicolumn{5}{|c|}{ Null: Unit root (assumes individual unit root process) } \\
\hline \multicolumn{5}{|c|}{ Panel unit root test: Summary } \\
\hline \multicolumn{5}{|l|}{ Series: MALES } \\
\hline \multicolumn{5}{|l|}{ Sample: 20102018} \\
\hline \multicolumn{5}{|c|}{ Exogenous variables: Individual effects } \\
\hline \multicolumn{5}{|c|}{ Newey-West automatic bandwidth selection and Bartlett kernel } \\
\hline \multicolumn{5}{|c|}{$\begin{array}{ll}+2 & \\
\end{array}$} \\
\hline Method & Statistic & Prob.** & $\begin{array}{l}\text { secti- } \\
\text { ons }\end{array}$ & Obs \\
\hline \multicolumn{5}{|c|}{ Null: Unit root (assumes common unit root process) } \\
\hline Levin, Lin \& Chu t* & -6.94938 & 0.0000 & 32 & 228 \\
\hline
\end{tabular}

Null: Unit root (assumes individual unit root process) 
SSTB

www.sstbdergisi.com

International Refereed Academic Journal of Sports, Health and Medical Sciences July - August - September Issue: 32 Summer Term Year: 2019

Uluslararası Hakemli Akademik Spor Sağlık ve Tıp Bilimleri Dergisi

Temmuz - Ağustos - Eylül Sayı: 32 Yaz Dönemi Yıl: 2019 ID:461 K:129

ISSN Print: 2146-8508 Online 2147-1711

(ISO 18001-OH-0090-13001706 / ISO 14001-EM-0090-13001706 / ISO 9001-QM-0090-13001706 / ISO 10002-CM-0090-13001706) (TRADEMARK)

(2015/04315- 2015-GE-18972)

\section{CAUSALITY ANALYSIS}

The causality analysis between the variables of OECD health statistics was examined with Granger test. The main hypothesis states that there is no causality between two series.

The findings below were obtained following the analysis.
- Antidepressant sales volume is a reason for consumption amount.

- Good/very good perceived health level of females is a reason for the antidepressant consumption amount.

- Good/very good perceived health level of males is not a reason for the antidepressant consumption amount.

\begin{tabular}{|c|c|c|c|}
\hline \multicolumn{4}{|l|}{ Pairwise Granger Causality Tests } \\
\hline \multicolumn{4}{|l|}{ Sample: 20102018} \\
\hline Null Hypothesis: & Obs & F-Statistic & Prob. \\
\hline CONSUMPTION does not Granger Cause SALES & 142 & 1.28194 & 0.2808 \\
\hline SALES does not Granger Cause CONSUMPTION & & 3.80487 & 0.0247 \\
\hline FEMALES does not Granger Cause SALES & 140 & 1.02194 & 0.3627 \\
\hline SALES does not Granger Cause FEMALES & & 0.88584 & 0.4148 \\
\hline MALES does not Granger Cause SALES & 140 & 0.93433 & 0.3954 \\
\hline SALES does not Granger Cause MALES & & 1.17831 & 0.3109 \\
\hline FEMALES does not Granger Cause CONSUMPTION & 142 & 3.94858 & 0.0215 \\
\hline CONSUMPTION does not Granger Cause FEMALES & & 0.21763 & 0.8047 \\
\hline MALES does not Granger Cause CONSUMPTION & 142 & 1.60242 & 0.2052 \\
\hline CONSUMPTION does not Granger Cause MALES & & 0.42224 & 0.6564 \\
\hline MALES does not Granger Cause FEMALES & 196 & 0.48715 & 0.6151 \\
\hline FEMALES does not Granger Cause MALES & & 0.25264 & 0.7770 \\
\hline
\end{tabular}


International Refereed Academic Journal of Sports, Health and Medical Sciences July - August - September Issue: 32 Summer Term Year: 2019

Uluslararası Hakemli Akademik Spor Sağlık ve Tıp Bilimleri Dergis Temmuz - Ağustos - Eylül Sayı: 32 Yaz Dönemi Yıl: 2019 ID:461 K:129

ISSN Print: 2146-8508 Online 2147-1711

(ISO 18001-OH-0090-13001706 / ISO 14001-EM-0090-13001706 / ISO 9001-QM-0090-13001706 / ISO 10002-CM-0090-13001706) (TRADEMARK)

REGRESSION ANALYSIS

REGRESSION ANALYSIS BETWEEN ANTIDEPRESSANT SALES VOLUME and PERCEIVED HEALTH LEVEL
- One unit of increase in antidepressant sales volume leads to 4.56 units of increase in perceived good/very good health levels of females.

\begin{tabular}{llllll}
\hline Dependent Variable & Independent Variable & Coefficient & Std. Error & t-Statistic & Prob. \\
\hline & & & & & \\
\hline FEMALE HEALTH & SALES & 4.560732 & 0.179650 & 25.38682 & 0.0000 \\
\hline
\end{tabular}

REGRESSION ANALYSIS BETWEEN ANTIDEPRESSANT SALES VOLUME and PERCEIVED HEALTH LEVEL
One unit of increase in antidepressant sales volume leads to 4.87 units of increase in perceived good/very good health levels of males.

\begin{tabular}{llllll}
\hline Dependent Variable & Independent Variable & Coefficient & Std. Error & t-Statistic & Prob. \\
\hline & & & & & \\
\hline MALE HEALTH & SALES & 4.877629 & 0.194137 & 25.12469 & 0.0000 \\
\hline
\end{tabular}

\section{REGRESSION ANALYSIS BETWEEN - One unit of increase in antidepressant ANTIDEPRESSANT CONSUMPTION consumption amount leads to 0.99 units AMOUNT and PERCEIVED HEALTH of increase in perceived good/very good LEVEL health levels of females.}

\begin{tabular}{llllll}
\hline Dependent Variable & Independent Variable & Coefficient & Std. Error & t-Statistic & Prob. \\
\hline & & & & & \\
\hline FEMALE HEALTH & CONSUMPTION & 0.990031 & 0.025563 & 38.72981 & 0.0000 \\
\hline
\end{tabular}


International Refereed Academic Journal of Sports, Health and Medical Sciences July - August - September Issue: 32 Summer Term Year: 2019

Uluslararası Hakemli Akademik Spor Sağlık ve Tıp Bilimleri Dergisi

Temmuz - Ağustos - Eylül Sayı: 32 Yaz Dönemi Yıl: 2019 ID:461 K:129

ISSN Print: 2146-8508 Online 2147-1711

(ISO 18001-OH-0090-13001706 / ISO 14001-EM-0090-13001706 / ISO 9001-QM-0090-13001706 / ISO 10002-CM-0090-13001706) (TRADEMARK)

(2015/04315- 2015-GE-18972)

\section{REGRESSION ANALYSIS BETWEEN ANTIDEPRESSANT CONSUMPTION AMOUNT and PERCEIVED HEALTH LEVEL}

- One unit of increase in antidepressant consumption amount leads to 1.06 units of increase in perceived good/very good health levels of males.

\begin{tabular}{llllll}
\hline Dependent Variable & Independent Variable & Coefficient & Std. Error & t-Statistic & Prob. \\
\hline & & & & & \\
\hline MALE HEALTH & CONSUMPTION & 1.060557 & 0.028570 & 37.12076 & 0.0000 \\
\hline
\end{tabular}

\section{CONCLUSION}

In the comparative study performed to determine antidepressant sales volume, consumption and health perception for males and females, antidepressant sales volume was realized to be highest in Canada among OECD countries and the consumption amount was found to be highest in Iceland. Perceived health level (good/very good) of females is the highest in New Zealand and highest in Canada for males among the OECD countries. Regarding antidepressant sales and consumption, it was found that the antidepressant sales volume and the perceived good/very good health level of females were a reason for the amount of antidepressant consumption while the perceived good/very good health level of males was not a reason for the antidepressant consumption amount. According to the regression analysis results, it has been established that one unit of increase in antidepressant sales volume leads to 4.56 units of increase in perceived good/very good health level of females and 4.87 units of increase in perceived good/very good health level of males while one unit of increase in consumption amount leads to 0.99 units of increase in perceived good/very good health level of females. As a result of the unit root analysis applied in the study, it has been concluded that antidepressant sales volume and consumption amount and perceived happiness level for both genders do not contain unit root; thus, they can be used in future analyses.

- Antidepressant sales are highest in Canada among the OECD countries.

- Antidepressant consumption amount is highest in Iceland among OECD countries.

- Perceived health level (good / very good) of females is highest in New Zealand among OECD countries. 
International Refereed Academic Journal of Sports, Health and Medical Sciences

July - August - September Issue: 32 Summer Term Year: 2019

Uluslararası Hakemli Akademik Spor Sağlık ve Tıp Bilimleri Dergisi

Temmuz - Ağustos - Eylül Sayı: 32 Yaz Dönemi Yıl: 2019 ID:461 K:129

ISSN Print: 2146-8508 Online 2147-1711

(ISO 18001-OH-0090-13001706 / ISO 14001-EM-0090-13001706 / ISO 9001-QM-0090-13001706 / ISO 10002-CM-0090-13001706) (TRADEMARK)

- Perceived health level (good / very good) of males is highest in Canada among OECD countries.

- Antidepressant sales volume does not contain unit root; therefore, it can be used in future analyses.

- Antidepressant consumption amount does not contain unit root; therefore, it can be used in future analyses.

- Perceived happiness level for both genders does not contain unit root and so, it can be used in future analyses.

- Antidepressant sales volume is a reason for consumption amount. Good/very good perceived health level of females is a reason for the antidepressant consumption amount. Good/very good perceived health level of males is not a reason for the antidepressant consumption amount.

- One unit of increase in antidepressant sales volume leads to 4.56 units of increase in perceived good/very good health levels of females.

- One unit of increase in antidepressant sales volume leads to 4.87 units of increase in perceived good/very good health levels of males.

- One unit of increase in antidepressant consumption amount leads to 0.99 units of increase in perceived good/very good health levels of females.

- One unit of increase in antidepressant consumption amount leads to 1.06 units of increase in perceived good/very good health levels of males.

\section{REFERENCES}

AYDIN, B., GELAL, A., (2012). "Ak1lc1 laç Kullanımı: Yaygınlastırılması ve Tıp Egitiminin Rolü” DEÜ Tıp Fakültesi Dergisi, Volume 26, p.57

AYLAZ, R., GÜLLÜ, E., GÜNEŞ, G., (2011). Aerobik Yürüme Egzersizin Depresif Belirtilere Etkisi, Dokuz Eylül Üniversitesi Hemşirelik Yüksekokulu Elektronik Dergisi; 4 (4): 172-177

BERGER, P.L., (1961). Some general observation on the problem of work. The Human Shape of Work. (Ed. P. Berger). New York: Macmillan

BERMAN, R.M., CAPPIELLO,A., ANAND, A., OREN, D.A., HENINGER, G.R., CHARNEY, D.S., KRYSTAL, J.H.., (2000). Antidepressant effects of ketamine in depressed patients. Biological psychiatry, 47(4): 351-354

DIK, G., AKAY, K., KAYACAN, Y., MAKARACI, Y., (2016). Sporcu ve Sedanter Ortopedik Engellilerde Depresyon Düze- 
International Refereed Academic Journal of Sports, Health and Medical Sciences July - August - September Issue: 32 Summer Term Year: 2019

Uluslararası Hakemli Akademik Spor Sağlık ve Tıp Bilimleri Dergisi Temmuz - Ağustos - Eylül Sayı: 32 Yaz Dönemi Yıl: 2019 ID:461 K:129

ISSN Print: 2146-8508 Online 2147-1711

(ISO 18001-OH-0090-13001706 / ISO 14001-EM-0090-13001706 / ISO 9001-QM-0090-13001706 / ISO 10002-CM-0090-13001706) (TRADEMARK)

yinin İncelenmesi. Gaziantep Üniversitesi Spor Bilimleri Dergisi, 1(2): 100-109

CONN, V.S., (2010). Depressive symptom outcomes of physical activity interventions: meta-analysis findings, Annals of Behavioral Medicine, 3, 128 - 138

CAREK, P.J., LAIBSTAIN, S.E., CAREK, S.M., (2011). Exercise for the treatment of depression and anxiety. International Journal of Psychiatry in Medicine, 41: $15-28$

FARIZ, B., (2015). Psikiyatrik Hastalıklar ve Egzersiz. Spor Hekimliği Dergisi, 50(4): 131-138

GIDDENS, A., (2000). Sosyoloji. Ankara: Ayraç

GOLDEN, R.N., GAYNES, B.N., EKSTROM, R.D., HAMER, R.M., JACOBSEN, F.M., SUPPES, T., WISNER, K.L., NEMEROFF, C.B., (2005). The efficacy of light therapy in the treatment of mood disorders: a review and metaanalysis of the evidence. American Journal of Psychiatry, 162(4): 656-662

JEONG, К.С., КОO, К.М., КIM, С.J., (2016). An Analysis on Relationships among Exercise Participation, Depression Experience, and Suicidal Ideation of People with Visual Impairment. Indian Journal of Science and Technology, 9(25)
KROGH, J., NORDENTOFT, M., STERNE, J.A., LAWLOR, D.A., (2011). The effect of exercise in clinically depressed adults: systematic review and meta-analysis of randomized controlled trials. Journal of Clinical Psychiatry, 72: 529 - 538

LAING, R.O., (1990). "Rational Drug Use: An Unsolved Problem", Tropical Doctor 1990 ,

20: $101-103$

MEAD. G.E., MORLEY, W., CAMPBELL, P., GREIG, C.A., McMUNDO, M., LAWLOR. D.A., (2008). Exercise for depression. Cochrane Database Syst Rev., Oct 8(4):CD004366

OECD (2012). “OECD Health Data 2012", http://www.oecd.org/health/healthsystems/ oecdhealthdata2012.htm (Accessed 01.01.2019)

PERRATON, L.G., KUMAR, S., MACHOT$K A, Z$. (2010). Exercise parameters in the treatment of clinical depression: a systematic review of randomized controlled trials. Journal of evaluation in clinical practice, 16(3): 597-604

SCHLOESSER, R.J., JIMENEZ, D.V., ORVOEN, S., HARDY, N.F., MAYNARD, K.R., SUKUMAR, M., GARDIER, A.M., DAVID, D.J., MARTINOWICH, K., (2015). Electroconvulsive treatment 
International Refereed Academic Journal of Sports, Health and Medical Sciences

July - August - September Issue: 32 Summer Term Year: 2019

Uluslararası Hakemli Akademik Spor Sağlık ve Tıp Bilimleri Dergisi

Temmuz - Ağustos - Eylül Sayı: 32 Yaz Dönemi Yıl: 2019 ID:461 K:129

ISSN Print: 2146-8508 Online 2147-1711

(ISO 18001-OH-0090-13001706 / ISO 14001-EM-0090-13001706 / ISO 9001-QM-0090-13001706 / ISO 10002-CM-0090-13001706) (TRADEMARK)

requires adult neurogenesis to rescue behavior in a mouse model of stress induced depression. Brain Stimulation: Basic, Translational, and Clinical Research in Neuromodulation, 8(2): 385

STANTON, R., REABURN, P., (2014). Exercise and the treatment of depression: A review of the exercise program variables, Journal of Science and Medicine in Sport, 17: 177- 182

STROHLE, A., (2009). Physical activity, exercise, depression and anxiety disorders. Journal of neural transmission, 116(6): 777-784

ŞENOL, M., (2010). "Koruyucu Hekimlik Açısından Dermatolojide Akılcı İlaç Kullanımı", Türkiye Klinikleri J Dermatol-Special Topics, p.145

TINAR, M.Y., (1996). Çalışma Psikolojisi. İzmir: Necdet Bükey

ULUSOY, H.B., SUNMAK, T., (2011). 'Kayseri'de Pratisyen Hekimlere Verilen Groningen Modeli Akılcı İlaç Kullanımı Eğitiminin Değerlendirilmesi”, Erciyes Tıp Dergisi, 33(4): p.310
WHO (2002). "Promoting Rational Use of Medicines: Core Components", http:// apps.who.int/medicinedoes/pdf (Accessed 01.01.2019)

WHO (2001). "How to Develop and Implement a National Drug Policy", Geneva, http://apps.who.int/medicinedocs/pdf/s2283e/s2283e.pdf (Accessed 01.01.2019)

YAPICI, G., BALIKÇI, S., ÖZGE, U., (2001). "Birinci Basamak Sağlık Kurulusuna Başvuranların İlaç Kullanımı Konusundaki Tutum ve Davranışları”, Dicle Tıp Dergisi, 38(4): p.459

\section{INTERNET RESOURCES}

https:/www.medonalds.com.tr/kampanyalar/ kulahima- (Accessed 01.01.2019)

anlat\#utm_source=programmatic\&utm medium $=$ cpc\&utm_campaign $=$ banner (Accessed 01.01.2019)

http://www.turkishtimedergi.com/genel/isegiris-mulakatinda-basarili-olmak/ (Accessed 01.01.2019)

https://onedio.com/haber/turkiye-deantidepresan-kullanimi-son-5-yildayuzde-27-artti-peki-neden-851773 